\title{
Article \\ Water rehydration capacity analysis of different types of dried fish products at different water temperature stored at ambient and refrigeration condition
}

\author{
Md. Masud Rana ${ }^{1} *$, Nusrat Hossain Nushy ${ }^{2}$, Sonia Sharmin ${ }^{2}$ and Subhash Chandra Chakraborty ${ }^{3}$ \\ ${ }^{1}$ Department of Fisheries Technology, Bangladesh Agricultural University, Mymensingh-2202, Bangladesh \\ ${ }^{2}$ Department of Fisheries Management, Bangladesh Agricultural University, Mymensingh-2202, Bangladesh \\ ${ }^{2}$ Bangladesh Fisheries Research Institute, Freshwater Station, Mymensingh, Bangladesh \\ ${ }^{3}$ Department of Fisheries Technology, Bangladesh Agricultural University, Mymensingh-2202, Bangladesh
}

*Corresponding author: Md. Masud Rana, Department of Fisheries Technology, Bangladesh Agricultural University, Mymensingh-2202, Bangladesh. E-mail: mmrana.hstu.ac.bd@ gmail.com

Received: 25 February 2018/Accepted: 14 March 2018/ Published: 29 March 2018

\begin{abstract}
Water rehydration capacity of the fishes named tengra (Mystus tengara) and batashi (Neotropious atherinoides) were studied in order to evaluate their eating quality. The initial value of protein, fat and ash content of Salt-Smoke-Dried (SSD) tengra and batashi was 63.40, 19.95 and 16.55\%; 65.93, 17.09 and 16.90\%, respectively on dry matter basis. Maximum Rehydration capacity obtained from salt-smoke-dried batashi and minimum value obtained from traditional dried tengra before storage at $28{ }^{\circ} \mathrm{C}$ temperature and its range varied between 17.68 to $50.38 \%$. The reconstitution capacity of the products at $28^{\circ} \mathrm{C}$ after the two month storage was in the range of 36.15 to $47.22 \%$ with minimum value for SSD tengra stored at ambient temperature after soaking 15 and maximum value obtained from SSD tengra stored at refrigeration temperature after 60 min soaking in water. After two month storage at $40^{\circ} \mathrm{C}$ the water reconstitution capacity was in the range of 38.24 to $54.78 \%$ with lowest value for control dried (CD; treated without salt and smoke) tengra stored at ambient temperature after soaking $15 \mathrm{~min}$ and highest value obtained from SSD batashi stored at refrigeration temperature after soaking $60 \mathrm{~min}$ in water. On the other hand at $60^{\circ} \mathrm{C}$ the reconstitution capacity after two month storage was in the range of 40.0 to $68.55 \%$ with minimum value for CD tengra stored at ambient temperature soaked after $15 \mathrm{~min}$ and maximum value for SSD batashi stored at refrigeration temperature soaked after $60 \mathrm{~min}$ in water. The reconstitution percentage was completely high at $60^{\circ} \mathrm{C}$ after soaking for $60 \mathrm{~min}$ for most of the samples.
\end{abstract}

Keywords: rehydration; salt-smoke-dried; traditional dried; tengra; batashi

\section{Introduction}

Fish plays a major role in the Bangladesh diet, constituting the only animal protein source among rural poor households (Shamsuddin et al., 2012). Bangladesh is also one of many developing countries to experience the proliferation of aquaculture, now the world's fastest growing food production sector, during a period of decline in capture fisheries (Belton and Thilsted, 2014). The physical and organoleptic qualities of most of the traditional dried fish products available in the market are not satisfactory for human consumption due to various reasons. There are frequent complaints from the consumers about the quality of the products and the major problems associated with sun drying of fish are the infestations. The processing and preservation of fresh fish are most important since fish is highly susceptible to deterioration immediately after harvest and also to prevent economic losses (Okonta and Ekelemu, 2005). Limitation of adequate fish handling, processing techniques and storage facilities contribute significantly low supply of fish to poor rural dwellers that form three quarters of the population in developing countries (Ayuba and Omejii, 2006). Fish occupies the foremost places among the food products of animal origin (meat, poultry, milk, eggs etc.) in nutritive value because of the presence of valuable 
proteins, lipids, vitamins and various kinds of mineral substances. Spoilage of fish begins as soon after the fish dies. Spoilage is the result of a series of complicated changes brought about in the dead fish mainly by enzymes and bacteria. These changes ultimately result in the organoleptic, chemical and biochemical change in fish. These changes can be reduced by using proper preservation method. The present investigation reports the proximate composition and determination of water reconstitution properties of salt-smoke-dried, control dried and traditional dried products prepared from tengra and batashi which gives clear idea about the eating quality of this product.

\section{Materials and Methods}

Moisture absorbed by dried fish immersed in water at a certain temperature and time is called water reconstitution or rehydration. It is one of the most important physical parameter to assess the quality of the dried and smoke dried products and expressed as percent water reconstitution under the defined condition.

In this process eight batashi fish of about $5 \mathrm{grams}$ and four tengra fish near about $5 \mathrm{~g}$ were kept soaked in water at temperatures of $28^{\circ} \mathrm{C}, 40^{\circ} \mathrm{C}$ and $60^{\circ} \mathrm{C}$ up to 60 minutes with occasional stirring. Water was drained off through a coarse nylon net. All the fish was then transferred to the strainer and extraneous water was removed off by a piece of blotting paper and fish was weighed.

The percent gain or uptake of moisture by the fish flesh was marked as percent water reconstitution or rehydration (\%) and calculated by using the following formula:

Water reconstitution $(\%)=\frac{\mathrm{Wr}-\mathrm{Wi}}{\mathrm{W}_{\mathrm{i}}} \times 100$

Where,

$\mathrm{W}_{\mathrm{i}}=$ Initial weight of the dry fish

$\mathrm{Wr}=$ Weight of the dry fish after water absorption.

\section{Results and Discussion}

Water rehydration capacity of salt-smoke-dried (SSD), control dried (CD) and traditional dried (TD) tengra and batashi are shown in the Figure 1, 2 and 3 respectively. The rehydration level of salt-smoke-dried and control dried tengra and batashi at $28^{\circ} \mathrm{C}$ was in the range of 42.52 to $50.38 \%$ with lowest value for control dried batashi after 15 min soaking in water, highest value obtained from salt-smoke-dried batashi after 60 min soaking (Figure 1). The reconstitution level was increased with the increment of time and temperature, at $40^{\circ} \mathrm{C}$ water rehydration capacity of those products was in the range of 45.33 to $58.22 \%$ with minimum value for control dried tengra after 15 min soaking in water and maximum value was found in salt-smoke-dried batashi after 60 min soaking.

At $60^{\circ} \mathrm{C}$ water rehydration capacity of those products was found in the range of 48.21 to $74.64 \%$ with minimum value for control dried tengra after 15 min soaking and maximum value obtained from salt-smoke-dried batashi after 60 min soaking in water. The percentage of rehydration increased with the increment of soaking time and the uptake of water was maximum after $60 \mathrm{~min}$ of soaking. On the other hand the percentage of water rehydration capacity decreased with strengthening the storage period due to the slow increase of moisture content in the samples. After two month stored at ambient temperature the reconstitution level at $28^{0} \mathrm{C}$ was in the range of 35.40 to $44.06 \%$ with lowest value for control dried tengra after 15 min soaking and highest value obtained from salt-smoke-dried batashi after 60 min soaking in water (Figure 2). On the other hand products stored at refrigeration temperature showed the range at the same temperature 40.64 to $47.22 \%$ with minimum value for control dried batashi after 15 min soaking and maximum value obtained from salt-smoke-dried tengra after 60 min soaking in water.

At $60^{\circ} \mathrm{C}$ the rehydration capacity was in the range of 40.0 to $66.82 \%$ with lowest value for control dried tengra after 15 min soaking and highest value observed in salt-smoke-dried after 60 min soaking in water in case of ambient storage condition. At the same temperature rehydration capacity for the products stored at refrigeration condition was in the range of 48.46 to $68.55 \%$ with maximum value obtained from salt-smoke-dried batashi after 60 min soaking and minimum value for control dried tengra after 15 min soaking in water. The initial water rehydration capacity of traditional dried products at $28^{\circ} \mathrm{C}$ was in the range of 17.68 to $32.33 \%$ with maximum value for batashi after 60 min soaking and minimum value obtained from tengra after 15 min soaking in water whereas at $60^{\circ} \mathrm{C}$ the rehydration capacity was found increased in the range of 34.3 to $53.76 \%$ with lowest value for batashi after 15 min soaking and highest value was found in tengra after 60 min soaking in water (Figure 3). Rehydration behavior of traditional dried samples stored at ambient condition (45 days) at 
$28^{0} \mathrm{C}$ were decreased to the range of 13.63 to $28.65 \%$ with minimum value for batashi after 15 min soaking and maximum value obtained from tengra after $60 \mathrm{~min}$ soaking in water. These values slowly increased at $60^{\circ} \mathrm{C}$ in the range of 23.87 to $40.48 \%$, the maximum value obtained from batashi after 60 min soaking and minimum value was found in tengra after 15 min soaking in water. It was also observed that the rehydration values of saltsmoke-dried fishes were significantly higher than those of traditional sun dried fishes when water reconstitution behavior was compared between the test samples. At low values, water uptake proceeds more quickly. In properly dried fish the water uptake is reported to complete in 3-15 minutes (Sikorski et al., 1995).
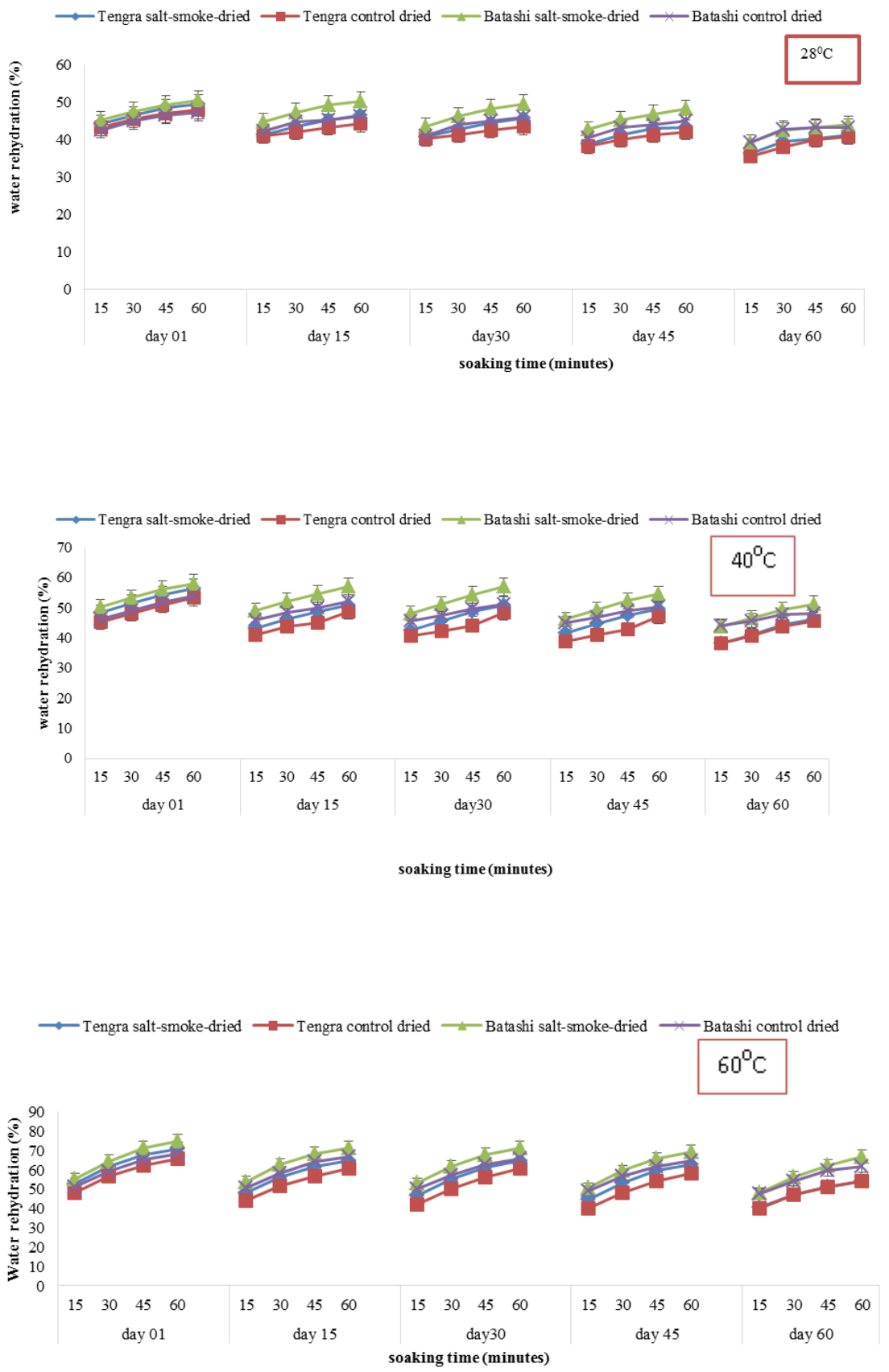

Figure 1. Changing pattern of water rehydration of tengra and batashi in two treatments SSD and CD soaked for $15,30,45$ and 60 minutes at ambient $\left(28^{\circ}\right), 40^{\circ}$ and $60^{\circ} \mathrm{C}$ temperature respectively for the products stored at ambient condition. 

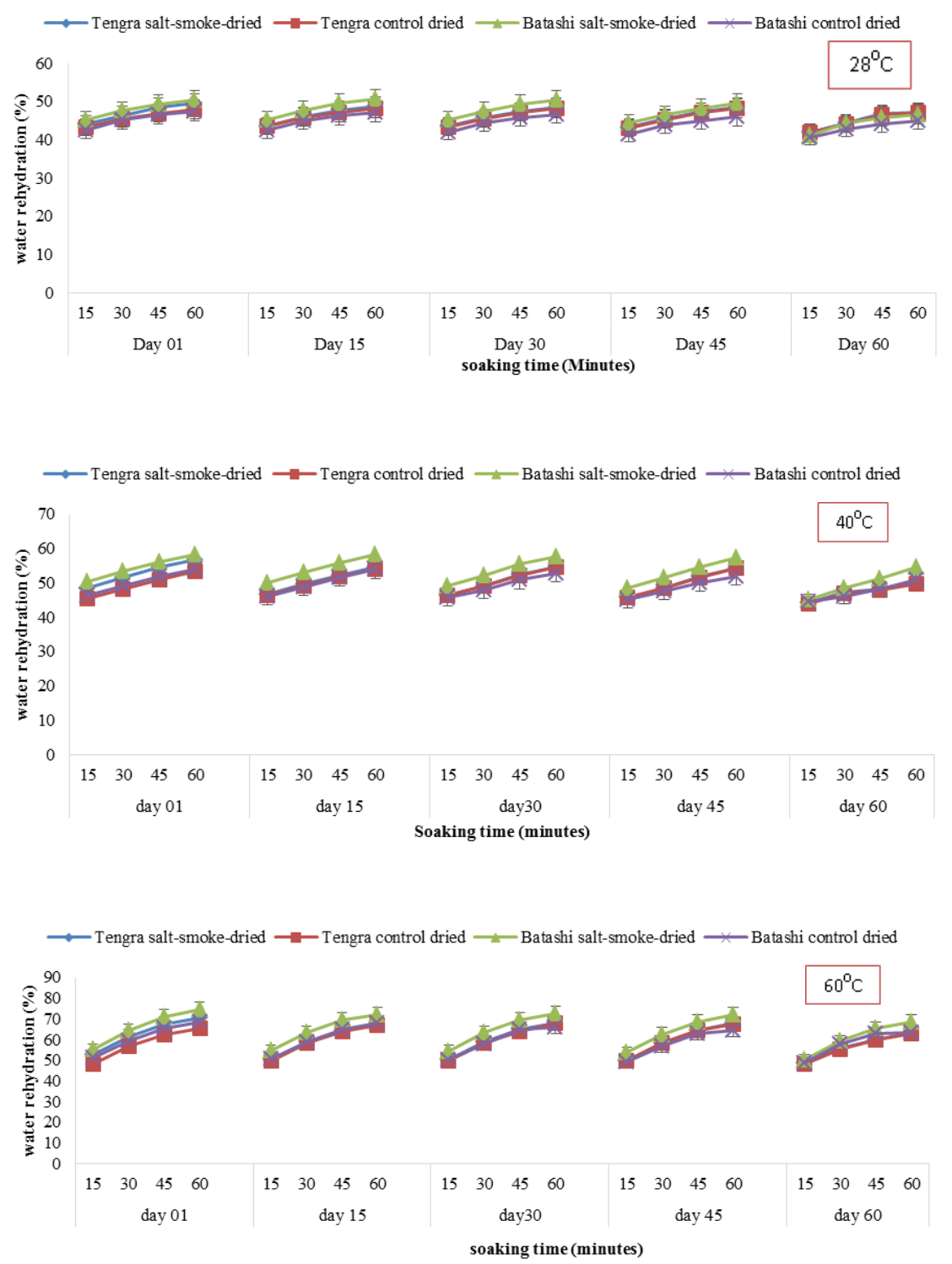

Figure 2. Changing pattern of water rehydration of tengra and batashi in two treatments SSD and CD soaked for $15,30,45$ and 60 minutes at ambient $\left(28^{\circ}\right), 40^{\circ}$ and $60^{\circ} \mathrm{C}$ temperature respectively for the products stored at refrigeration condition.

The $C$. straitus and $L$. rohita exhibited an enormously rapid initial rate of rehydration. This is due to water being carried into the deep part of the piece by a porous structure which absorbed and retained sufficient water by capillary which is similar with the present study (Mansuer et al., 2013). With a tough and rubbery tissue water penetrates mostly to the centre of large pieces by diffusion through the protein of the fibre itself and the process is very slow (Connell, 1957). A similar study by Nurullah et al. (2006) observed the maximum reconstitution capacity of solar dried tengra, batashi and other small indigenous species was obtained at $80^{\circ} \mathrm{C}$ was in the range of 65.26 to $70.51 \%$ where the percentage of reconstitution increased with the increase of soaking time and reached maximum at the end of up to $60 \mathrm{~min}$. Hasan et al. (2006) showed that the maximum reconstitution capacity in the range of 30.69 to $56.66 \%, 35.62$ to 66.24 and 48.46 to $78.94 \%$ in the samples (mola, tengra and katchki) soaked after $60 \mathrm{~min}$ on solar tunnel drier at $30^{\circ} \mathrm{C}, 40^{\circ} \mathrm{C}$ and $60^{\circ} \mathrm{C}$ temperature, respectively which are more or less similar with the present study. 

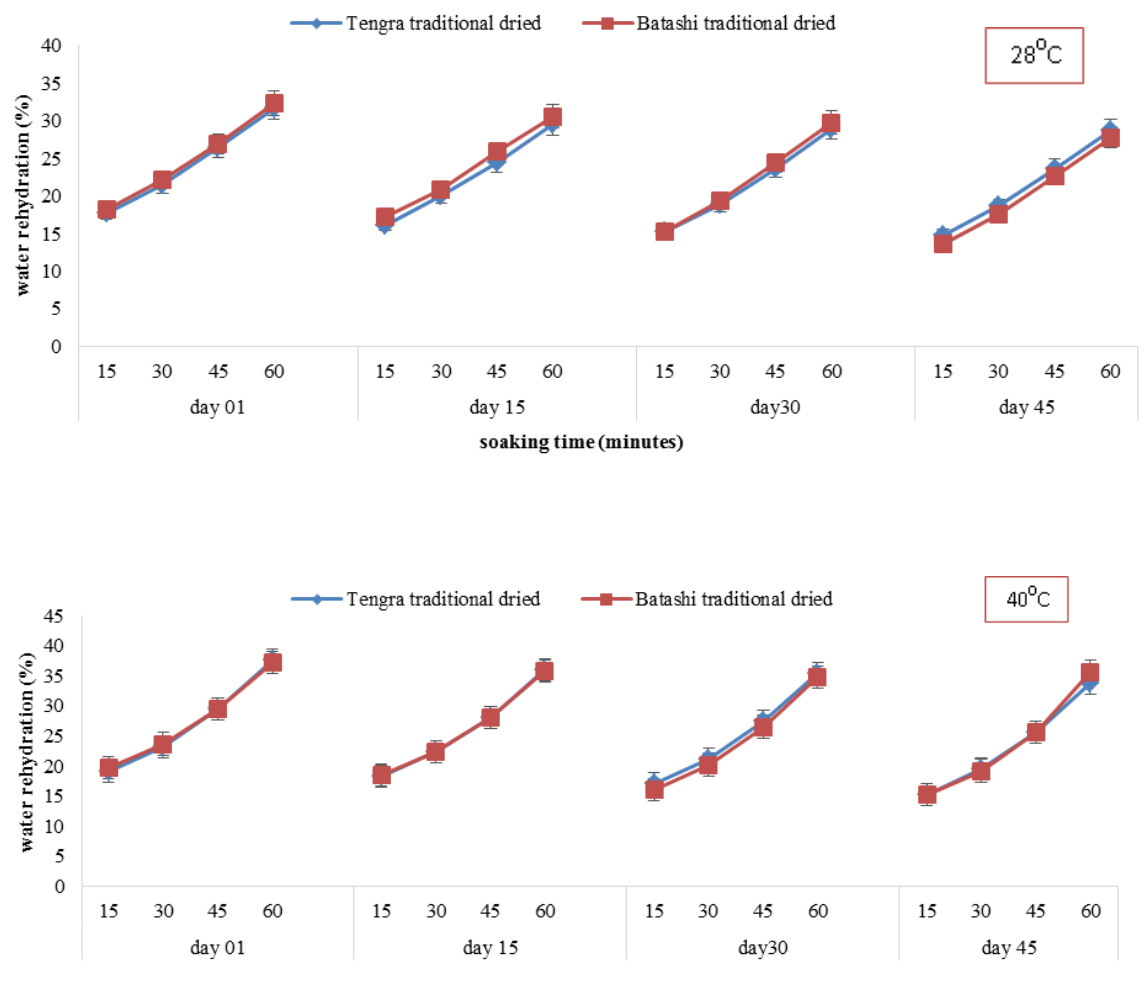

soaking time (minutes)

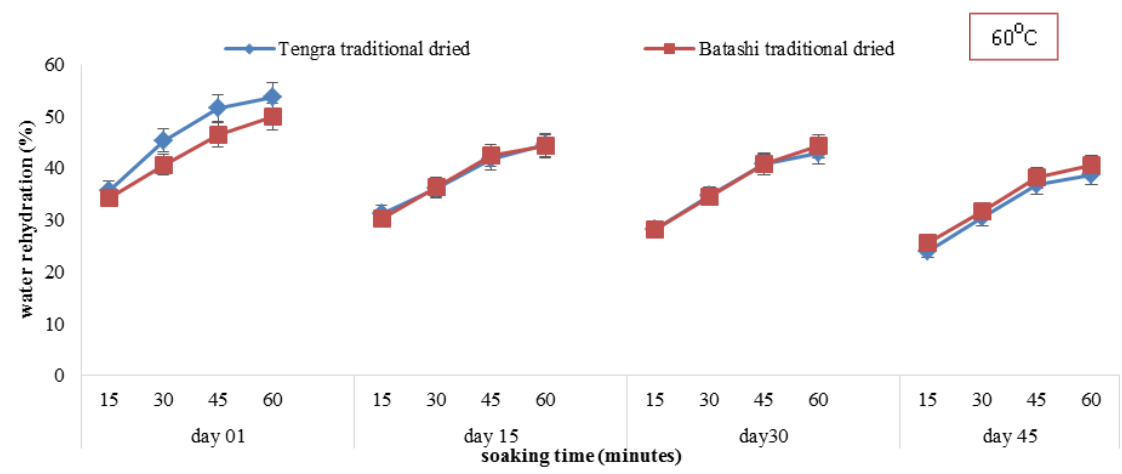

Figure 3. Changing pattern of water rehydration of traditional dried tengra and batashi soaked for 15, 30,45 and 60 minutes at ambient $\left(28^{\circ}\right), 40^{\circ}$ and $60^{\circ} \mathrm{C}$ temperature respectively for the products stored at ambient condition

\section{Conclusions}

The present study showed the reconstitution behavior of freshwater small fishes; tengra and batashi, it also provides a possible application of salt-smoke-drying as an efficient drying for fish preservation. Considering the rehydration capacity, it can be stated that salt-smoke-dried (SSD) products were better quality compared to control dried (CD) and traditional dried (TD) products. Comparatively the quality of salt-smoke-dried fish at ambient temperature deteriorates quickly and it is recommended that further study be conducted on shelf-life using refrigeration temperature.

\section{Conflict of interest}

None to declare.

\section{References}

Asita AO, IA Campbell, 1990. Anti-microbial activity of smoke from different woods. Lett. Appl. Microbial., 10:93-95. 
Ayuba VO and NO Omejii, 2006. Effect insect infestation on shelf life of smoked dried fish. Proceedings of the $21^{\text {st }}$, Annual Conference of the Fisheries Society of Nigeria. Calabar, Nigeria. pp. 357-359.

Belton B and SH Thilsted, 2014. Fisheries in transition: Food and nutrition security implications for the global South. Global Food Security, 3: 59-66.

Chakraborty SC, 2003. A study on proximate composition of common fresh water fishes of Bangladesh. Bangladesh J. Fish., 26: 23-36.

Clucas IJ and AR Ward, 1996. Post harvest fisheries development. A guide to handling, preservation, processing and quality. Chatham Maritime, Kent ME4TB, United Kingdom. pp. 665

Connell JJ, 1957. Some quality aspects of the texture of dehydrated fish. L. Sci. Hood Agric., 8: 526-537.

Hasan MM, FH Shikha, MI Hossain, M Kamal, MN Islam and MA Wahab, 2006. Quality assessments of traditional, rotary and solar tunnel dried small indigenous fish products. Bangladesh J. Fish. Res., 10: 73-84.

Mansur MA, MN Islam, SC Chakraborty and FA Chaity, 1990. A comparative study on the traditional and solar tent dried fish. Bangladesh J. Fish., 13: 33-39.

Mansur MA, S Rahman, MNA Khan, MS Reza, Kamrunnahar and S Uga, 2013. Study on the quality and safety aspect of three sun-dried fish. African Journal of Agricultural Research, 8: 5149-5155.

Nurullah M, M Kamal, MA Wahab, MN Islam, MS Reza, SH Thilsted and MA Mazid, 2006. Quality assessments of traditional and solar tunnel dried SIS (Small Indigenous Fish Species) products. Bangladesh J. Fish. Res., 10: 63-72.

Okonta AA and JK Ekelemu, 2005. A preliminary study of microorganisms associated with fish spoilage in Asaba, Southern Nigeria. Proceedings of the 20th Annual Conference of the Fisheries Society of Nigeria (FISON), Port Harcourt, $14^{\text {th }}$ to 18 th November, pp.557-560.

Shamsuddin M, MB Hossain, MM Rahman, M Asadujjaman and MY Ali, 2012. Performance of mono sex fry production of two Nile tilapia strains: semi intensive cultured fishes than the waterlogged GIFT and NEW GIPU. World J. Fish and Mar. Sci., 4: 68-72.

Sikorski ZE, A Gildberg and A Ruiter, 1995. Fishery products, composition, nutritive properties and stability. Ed. By Ruiter A, Depart, CAB International, The Netherlands. 